ISSN1027-5495. Functional Materials, 23, No.2 (2016), p. 344-350

\title{
Evidence of hydroxyl radical created by DBD plasma in water and its application in dye wastewater remediation
}

\author{
Wang Ying ${ }^{1,2}$, Wang Weiwei ${ }^{1}$, Ji Yingchao ${ }^{1}$, \\ Li Hong ${ }^{1}$, Wang Qiuhong ${ }^{1}$ \\ ${ }^{1}$ School of Textile and Material Engineering, \\ ${ }^{2}$ National Engineering Research Center of Seafood, Dalian Polytechnic \\ University, Dalian, Liaoning, 116034, P.R. China
}

Received October 12, 2015

\begin{abstract}
Dye wastewater remediation becomes a global concern. In this paper DBD plasma technology was used for water treatment. To find the evidence of hydroxyl radical created by DBD plasma in water, crystal violet (CV) was used as the radical indictor. The results showed that the hydroxyl radicals can survive longer in water solution than in gaseous state. Water increased the dye decoloration efficiency. Then CV and Methyl Orange (MO) solutions were chosen as dye wastewater. During plasma discharge, a large number of strong hydroxyl radicals in water attacked the dye molecules, resulting in the bleaching of the solution. The color groups of the CV and MO dye were effectively decomposed by plasma. The decoloration rate of the dye solutions was promoted with the increasing of plasma treatment time. $0.1 \%$ CV solution needed $2 \mathrm{~min}$ to fade and $0.1 \% \mathrm{MO}$ solution needed $3 \mathrm{~min}$ to fade at the discharge condition of $100 \mathrm{~W}$ and $8 \mathrm{~mm}$. The energy yields obtained in this investigation were $0.24 \mathrm{~g} / \mathrm{kWh}$ for MO dye and $0.36 \mathrm{~g} / \mathrm{kWh}$ for CV dye.

Keywords: DBD plasma, hydroxyl radical, crystal violet dye, methyl orange dye, dye wastewater remediation.
\end{abstract}

\footnotetext{
Очистка сточных вод от красителей является глобальной проблемой. В представленной работе для определения качества воды применялась плазменная технология диэлектрического барьерного разряда (DBD). Для того чтобы найти доказательства присутствия гидроксильного радикала, образованного в воде при использовании плазменной технологии DBD, в качестве радикального индикатора применяли кристаллический фриолетовый (CV) индикатор. Результаты показали, что гидроксильные радикалы могут уцелеть дольше в водном растворе, чем в газообразном состоянии. Вода повышает эфрфективность обесцвечивания красителя. Затем растворы CV и метилового оранжевого (MO) были выбраны в качестве сточной воды, загрязненной красителем. Во время плазменного разряда большое количество прочных гидроксильных радикалов атаковали молекулы красителя в воде, что привело к обесцвечиванию раствора. Цветовые группы красителей CV и MO эффективно разрушились под воздействием плазмы. Скорость обесцвечивания растворов красителей повышалась с увеличением времени обработки плазмой. Для обесцвечивания $0,1 \%$ раствора CV необходимо 2 мин., а для $0,1 \%$ раствора МО - 3 мин при мощности разряда 100 Вт и разрядном промежутке 8 мм. Энергетические выходы, полученные в этом исследовании, составляли 0,24 г / кВт · ч для MO и 0,36 г / кВ $\cdot$ ч для CV.Свидетельства присутствия гидроксильного радикала, образуемого плазмой ДБР в воде, и их использование для очистки сточных вод от красителей
} 
Свідоцтва наявності гідроксильного радикала, утвореного плазсою ДБР в воді, та їх застосування для очищення стічних вод від барвників. Ван $I_{н}$, Ван Вейвей, Цзі Інчао, Лі Хун, Ван Цюхун

Очищення стічних вод від фрарбників є глобальною проблемою. У представленій роботі для визначення якості води застосовувалася плазмова технологія діелектричного бар'ерного розряду (DBD). Для того, щоб знайти докази присутності гідроксильного радикала, утвореного у воді при використанні плазмової технології DBD, як радикальний індикатор застосовували кристалічний фіолетовий (CV) індикатор. Результати показали, що гідроксильні радикали можуть уціліти довше у водному розчині, чим в газоподібному стані. Вода підвищуе ефективність знебварвлення фрарбника. Потім розчини CV і метилового оранжевого (МО) були вибрані як стічна вода, забруднена фарбником. Під час плазмового розряду велику кількість міцних гідроксильних радикалів атакували молекули фарбника у воді, що привело до знебварвлення розчину. Колірні групи фрарбників CV і MO ефективно руйнувалися під впливом плазми.

\section{Introduction}

Dye compounds as a major group of pollutants in wastewater are of concern worldwide due to their severe problems for the environment and human health. Thus, in the cases of unavoidable pollutant emissions, these emerging compounds must be treated to satisfy the stringent water quality regulations before discharging into aquatic ecosystem. Nowadays, significant attention is focusing on plasma oxidation processes.

Plasma is a partially or fully ionized gas consisting of electrons, free radicals, ions and neutrals [1]. All varieties of plasma systems are traditionally defined into two major categories, namely thermal and non-thermal, in terms of electronic density and temperature. Thermal plasma (usually arc discharges, torches or radio frequency) is associated with sufficient energy introduced to allow plasma constituents to be in thermal equilibrium. While non-thermal plasma is obtained using less power (usually corona discharge, dielectric barrier discharge, gliding arc discharge, glow discharge and spark discharge). It does not express a local thermodynamic equilibrium, which, therefore, offers high selectivity and energy efficiency in plasma chemical reactions.

Both thermal and non-thermal plasma technology can obtain an oxidation environment by controlling discharge condition. During the plasma discharge, plasma technology leads to various physical and chemical effects, such as radical species and UV light. Among these, reactive species especially hydroxyl $(\mathrm{OH})$ radicals are produced, which has highly reactive to damage all types of macromolecules. Its standard potentials are up to $2.8 \mathrm{~V}$. So, the main advantage of plasma oxidation lies in the generation of highly reactive species which are theoretically able to oxidize any organic pollution in the liquid medium with minimal harm to environment. It has been suggested as a major cause of organic pollution degradation.
In view of these facts, applications of atmospheric pressure plasma technologies for water treatment attract the increasing interest and emerge as technological opportunities for the plasma community [2-4]. It also has characteristics such as no secondary pollution, normal temperature and pressure, non-selective high removal efficiency, and low power consumption, thus is a promising technology for wastewater treatment. Although many experiments studies have been performed on all kinds of dye wastewater by plasma technologies, there remain many unknown questions about of radicals, including life time, diffusion rate, etc. Effective dye wastewater remediation by plasma requires understanding the interaction mechanism of the reaction of radicals with water.

Therefore in this paper, dielectric barrier discharge (DBD) [5-6] plasma technology, one of non-thermal plasma, was used for decolorizing organic dye solutions at atmospheric pressure. The created and survival evidence of $\mathrm{OH}$ radicals in water by DBD plasma discharge was investigated by using crystal violet (CV) as $\mathrm{OH}$ radical indicator. $\mathrm{CV}$ and Methyl orange (MO) were used as simulative wastewater. The factors affecting the degradation of organic pollutant, such as discharge time, discharge power and solution concentration were studied. Furthermore the possible interaction mechanics of radicals created by plasma with water was proposed.

\section{Materials and methods}

\subsection{Materials}

In the plasma diagnostic experiment, $\mathrm{CV}$ was used as indicator for $\mathrm{OH}$ radical. $\mathrm{CV}$ is also a kind of cationic dyes. MO is a kind of azo dyes. Then, $0.1 \%$ and $0.15 \% \mathrm{CV}$ solutions, and $0.1 \%$ and $0.3 \% \mathrm{MO}$ solutions were prepared, respectively. They were used as simulative wastewater. Their molecular formulas are listed in Fig. 1.

$\mathrm{FeSO}_{4} \cdot 7 \mathrm{H}_{2} \mathrm{O}, \mathrm{H}_{2} \mathrm{O}_{2}(30 \%)$ and n-butyl alcohol were purchased from Tianjin Kemiou Chemical 
<smiles>CN(C)c1ccc(C(c2ccc(N(C)C)cc2)c2ccc(N(C)C)cc2)cc1</smiles>

a)<smiles>CN(C)c1ccc(/N=N/c2ccc(S(=O)(=O)O[Na])cc2)cc1</smiles>

b)

Fig. 1. The molecular formulas of (a) CV and (b) MO

Table 1 The schedule of the tests

\begin{tabular}{|c|c|c|c|c|c|c|c|}
\hline Solution(ml) & $1 \#$ & $2 \#$ & $3 \#$ & $4 \#$ & $5 \#$ & $6 \#$ & $7 \#$ \\
\hline $0.1 \% \mathrm{CV}$ & 2 & 2 & 2 & 2 & 2 & 2 & 2 \\
\hline $0.03 \% \mathrm{FeSO}_{4}$ & 0 & 2 & 0 & 0.5 & 0.5 & 0 & 0 \\
\hline $0.03 \% \mathrm{H}_{2} \mathrm{O}_{2}$ & 0 & 0 & 2 & 0.5 & 0.5 & 0 & 0 \\
\hline n-butyl alcohol & 0 & 0 & 0 & 0 & 0.3 & 0 & 0.3 \\
\hline $\mathrm{H}_{2} \mathrm{O}$ & 2 & 0 & 0 & 1 & 0.7 & 0 & 0 \\
\hline $\begin{array}{c}* \mathrm{Plasma}_{\text {treated }} \mathrm{O} \\
2\end{array}$ & 0 & 0 & 0 & 0 & 0 & 2 & 1.7 \\
\hline
\end{tabular}

* CV solution or n-butyl alcohol was poured into plasma treated water immediately.

Reagent Co., Ltd., China. $\mathrm{FeSO}_{4} \cdot 7 \mathrm{H}_{2} \mathrm{O}$ and $\mathrm{H}_{2} \mathrm{O}_{2}$ are the reagents of Fenton's reaction. N-butyl alcohol is a kind of free radical trapping agent.

\subsection{Methods}

CTP1200 plasma treatment equipment was made by Coronalab, China. This reactor was showed in Fig. 2, which had been used in our previous reports [7]. The dielectric barrier of this reactor was quartz glass. The distance between quartz glasses was $8 \mathrm{~mm}$.

Plasma treated water was prepared as follows. Before the plasma discharge, $5 \mathrm{ml}$ of distilled water was placed on the surface of the quartz electrode. It was treated by plasma at discharge power of $100 \mathrm{~W}$, discharge gap of 8 $\mathrm{mm}$ and discharge time of $30 \mathrm{~s}$.

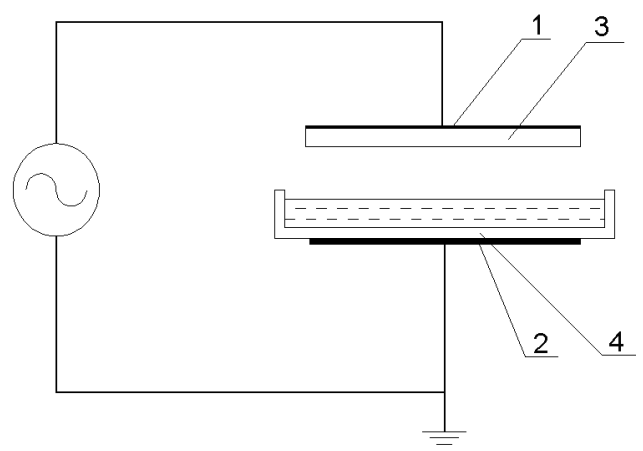

Fig. 2.The chart of plasma reactor: 1 and 2 electrodes, 3 and 4 barriers

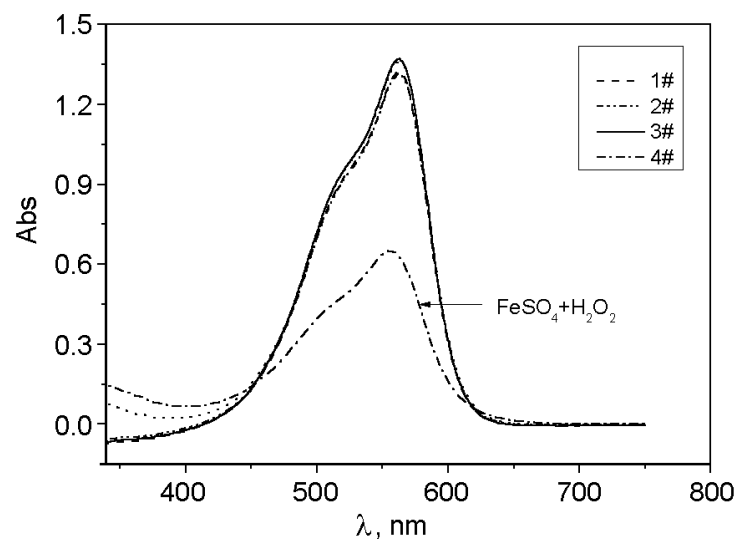

Fig. 3. UV-Vis spectra of samples 1 \#, 2 \#, 3 \# and 4 \#

In order to find the evidence of $\mathrm{OH}$ radical created by DBD plasma in water, Fenton's reagents, n-butyl alcohol and plasma treated water were added into the CV solutions, respectively. The schedules of the tests were listed in Table l.

Plasma treated dye solutions were prepared as follows. Before the plasma discharge, CV solutions or MO solutions were placed on the surface of the quartz electrode. The electrode distance was $8 \mathrm{~mm}$. The discharge powers were $90 \mathrm{~W}, 100 \mathrm{~W}$ and $110 \mathrm{~W}$, respectively. The discharge time was $20 \mathrm{~s}, 40 \mathrm{~s}, 60 \mathrm{~s}, 80 \mathrm{~s}, 100 \mathrm{~s}$ and $120 \mathrm{~s}$, respectively. A UV-Visible Spectrophotometer (UV5000, made by Nanjing Haohai Instrument Co., Ltd., China) was used to check the decoloration rate $(R, \%)$ of $\mathrm{CV}$ solution before and after the treatment processing. Before the UV-Visible absorbency experiment, the solutions were diluted to 20 times. The decoloration rate of dye solutions was calculated by the following Eq. (1):

where,

$$
R=\frac{A_{0}-A}{A_{0}} \times 100 \%
$$

$A_{0}$ - the initial absorbance before reaction; $A$ - the absorbance after reaction. 


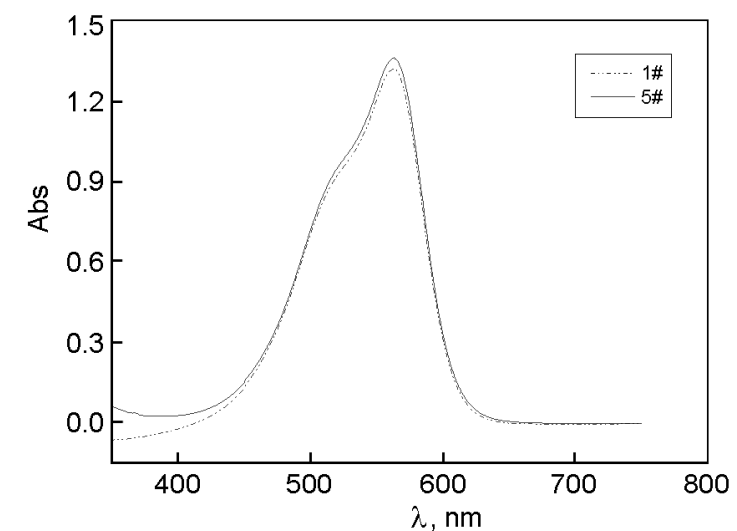

Fig. 4. UV-Vis spectra of samples 1 \# and 5 \#

\section{Results and discussion}

\subsection{Evidence of $\mathrm{OH}$ radical created by fenton's reaction}

Figure 3 was the spectra of samples $1 \#, 2$, 3 \# and 4 \#. For 1 \# samples, the characteristic absorption peak of CV dye was at $563 \mathrm{~nm}$ between 300-800 nm. For the 2 \# sample, CV solution and $\mathrm{FeSO}_{4}$, there was no difference about intensity and position of the absorption peak at $563 \mathrm{~nm}$. It is illustrated that there was no reaction between $\mathrm{CV}$ solution and $\mathrm{FeSO}_{4}$. The same results can be obtained in the 3 \# sample for $\mathrm{CV}$ solution and $\mathrm{H}_{2} \mathrm{O}_{2}$. However, for Fenton's reaction (4 \#), the characteristic absorption peak of CV dye decreased a lot. The decoloration rate of CV solution was $56 \%$ according to Eq. (1). It is proved that it produced large numbers of $\mathrm{OH}$ radicals through Fenton's reaction, in Eq. (2):

$$
\mathrm{Fe}^{2+}+\mathrm{H}_{2} \mathrm{O}_{2} \rightarrow \mathrm{Fe}^{3+}+\mathrm{OH}^{-}+\cdot \mathrm{OH} \text {. }
$$

So it is suggested that $\mathrm{OH}$ radicals was a major cause of organic pollution degradation. It is highly reactive to damage CV macromolecules in wastewater.

In order to further prove the $\mathrm{OH}$ radicals created by Fenton's reaction. The experiment of 5 \# was carried out and the results were listed in Fig. 4. Small amount of n-butyl alcohol was put into the Fenton's system. It was displayed that there was no change in the absorption peak of the CV solution after adding n-butyl alcohol into the Fenton's system. N-butyl alcohol is a kind of free radical trapping agent with a very high reaction rate constant $\left(1 \times 10^{8} \mathrm{~L} /(\mathrm{mol} . \mathrm{s})\right)$. In this experiment, it can inhibit the reaction of $\mathrm{OH}$ radicals with CV macromolecules. Therefore, it is illustrated that CV solution can be effectively used as $\mathrm{OH}$ radical indicator.

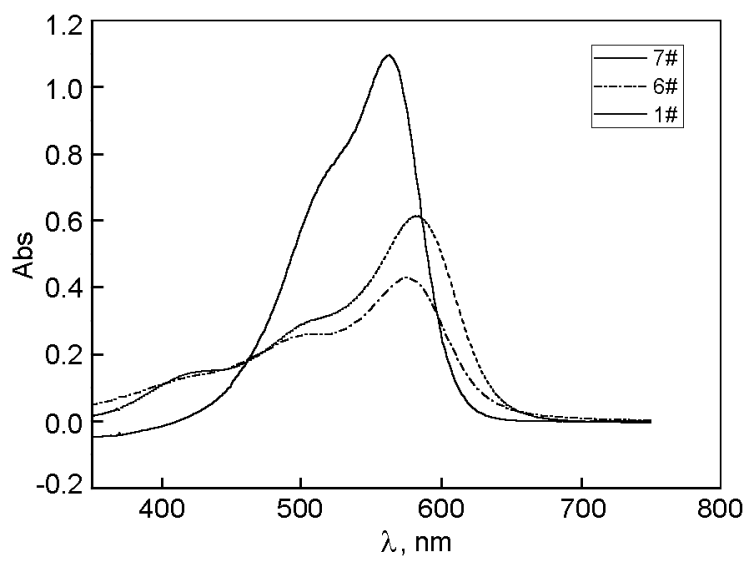

Fig. 5. UV-Vis spectra of samples1 \#, 6 \# and 7 \#

\subsection{Evidence of $\mathrm{OH}$ radical created by DBD plasma in water}

Figure 5 was the spectra of samples 1 \#, $6 \#$ and 7 \#. Sample 6 \# was the plasma treated water and CV solution. After the reaction of plasma treated water with CV, the absorbency of peaks at $563 \mathrm{~nm}$ shift a little to $575 \mathrm{~nm}$. The absorbency peak decreased and the R of CV solution was $65.3 \%$. After pouring n-butyl alcohol (sample 7 \#), the R of CV solution was $44 \%$, a little higher than 6 \#.

In the DBD plasma discharge, the energetic electrons can collide with background molecules $\left(\mathrm{N}_{2}, \mathrm{O}_{2}, \mathrm{H}_{2} \mathrm{O}\right.$, etc.) producing secondary electrons, photons, ions and radicals. It is reported that $\mathrm{O}$ atoms, $\mathrm{HO}_{2}$ radicals, $\mathrm{OH}$ radicals and $\mathrm{H}_{2} \mathrm{O}_{2}$ created during the air DBD plasma discharge [8-9]. Since n-butyl alcohol is free radical trapping agent, the increasing of absorbency proved that radicals created in the DBD plasma discharge. Maybe, it is $\mathrm{HO}_{2}$ or $\mathrm{OH}$ radicals. However, $\mathrm{HO}_{2}$ is a better proton donor but a weaker proton acceptor than water [10]. The experiment results also showed that the plasma treated water displayed acidity with the $\mathrm{pH}$ of 3.73. It was displayed that a large number of protons produced in water [11-12]. Then the reaction scheme for $\mathrm{HO}_{2}$ in water may be given in Eq. (3):

$$
\mathrm{HO}_{2} \cdot+\mathrm{H}_{2} \mathrm{O} \leftrightarrow\left[\mathrm{O}_{2}-\mathrm{H}-\mathrm{OH}_{2}\right] \leftrightarrow \mathrm{O}_{2}^{-}+\mathrm{H}_{3} \mathrm{O}^{+}
$$

Therefore, it is concluded that it is $\mathrm{OH}$ radicals, produced during plasma water discharge, attacked the dye molecules, resulting in the bleaching of the CV solution. It is to note that CV solution or n-butyl alcohol was poured into plasma treated water by hand. This needed as far as several seconds. Knowing that the life time of the $\mathrm{OH}$ radical is generally to be a few $\mu \mathrm{s}$ in a gaseous state. However, in our experiments, we detected $\mathrm{OH}$ radicals in water after discharge of several seconds. It is illustrated 


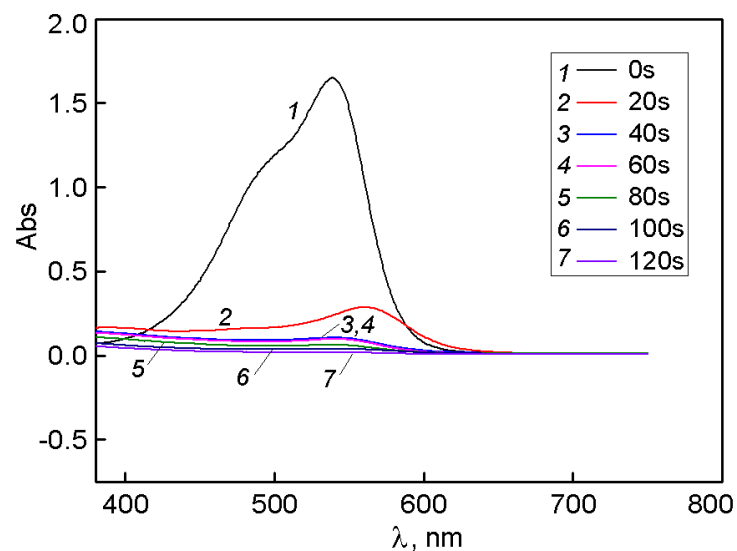

Fig. 6. The $\mathrm{R}$ of $\mathrm{CV}$ solutions at different discharge time $(100 \mathrm{~W}, 8 \mathrm{~mm})$

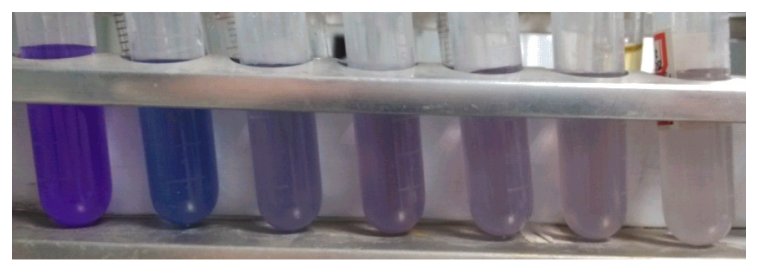

Fig. 7. The pictures of $\mathrm{CV}$ dye at discharge time of $0 \mathrm{~s}, 20 \mathrm{~s}, 40 \mathrm{~s}, 60 \mathrm{~s}, 80 \mathrm{~s}, 100 \mathrm{~s}$ and $120 \mathrm{~s}$

that the life time of hydroxyl radicals in water can be a few hundred times than that in gas state. Theoretical simulated calculation also showed that the interaction of $\mathrm{OH}$ radicals with water leads to the consecutive formation of another $\mathrm{OH}$ radical [10], listed in Eq. (4).

$$
\mathrm{HO}+\mathrm{H}_{2} \mathrm{O} \leftrightarrow[\mathrm{HO}-\mathrm{H}-\mathrm{OH}] \leftrightarrow \mathrm{H}_{2} \mathrm{O}+\mathrm{HO} \cdot
$$

Then, it is it displayed that the $\mathrm{OH}$ radical species created and survived longer that other reactive species in water solution. Water solution will increase the decoloration efficiency of dye.

\subsection{The optimal plasma discharge con- ditions of $C V$ wastewater remediation}

The CV solutions $(0.1 \%)$ were treated at $100 \mathrm{~W}, 8 \mathrm{~mm}$ and discharge time of $20 \mathrm{~s}, 40 \mathrm{~s}$, $60 \mathrm{~s}, 80 \mathrm{~s}, 100 \mathrm{~s}$ and $120 \mathrm{~s}$, respectively. The $\mathrm{R}$ of the CV solutions was displayed in Fig. 6. When the time increased, the $R$ of the CV solution was effectively increased. At the discharge time of 40 $\mathrm{s}$, the decoloration rate of the $\mathrm{CV}$ solution was as high as $93 \%$. With the extending of discharge time to $2 \mathrm{~min}$, the $R$ of the $\mathrm{CV}$ solution was nearly to $100 \%$. The pictures of CV solution at different discharge time were showed in Fig. 7. It is clear that the color of CV solution gradually fade. $0.1 \% \mathrm{CV}$ solution needed $2 \mathrm{~min}$ to fade at the discharge condition of $100 \mathrm{~W}$ and $8 \mathrm{~mm}$.

Figure 8 showed the results of the $R$ of $\mathrm{CV}$ solutions at different discharge power. With the increasing the discharge power, the $\mathrm{R}$ increased. Although the $R$ at $110 \mathrm{~W}$ was higher than $100 \mathrm{~W}$, the releasing heat and energy

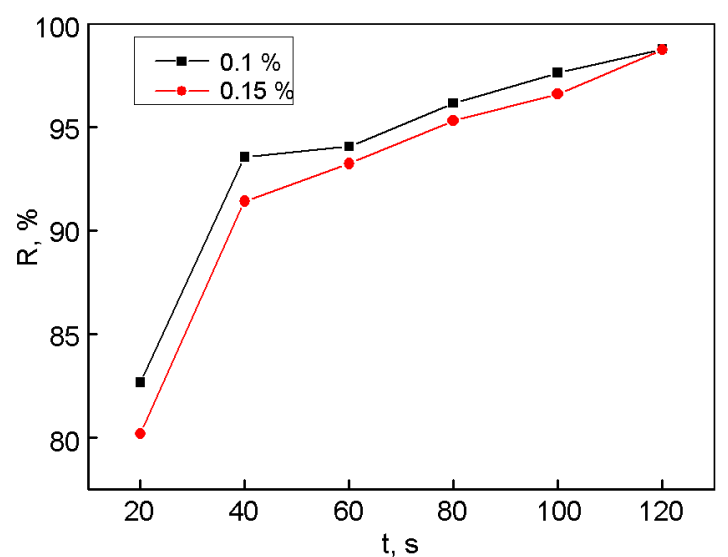

Fig. 8. The $\mathrm{R}$ of $\mathrm{CV}$ solutions at different discharge power

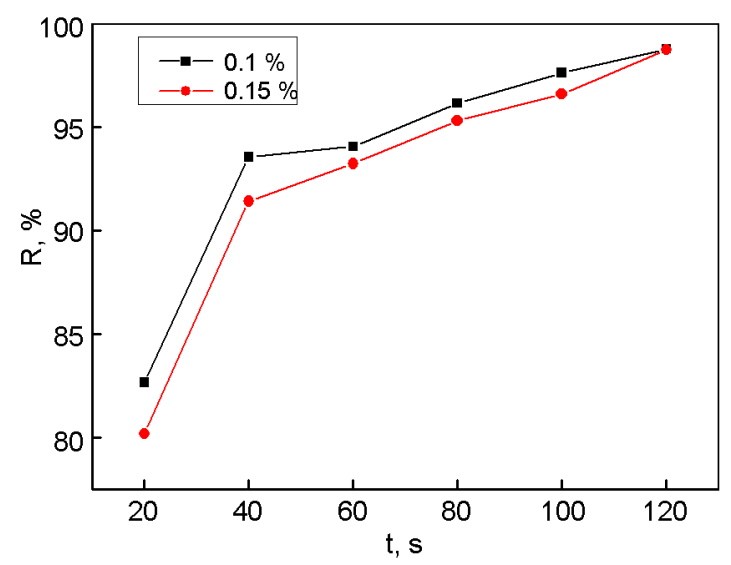

Fig. 9. The R of $0.1 \%$ and $0.5 \% \mathrm{CV}$ solutions $(100 \mathrm{~W}, 8 \mathrm{~mm})$

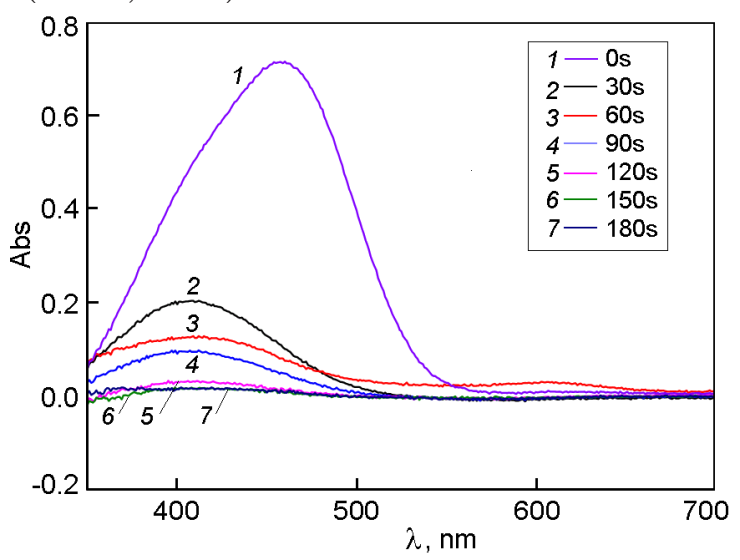

Fig. 10. The $\mathrm{R}$ of $0.1 \% \mathrm{CV}$ solutions at different discharge time $(100 \mathrm{~W}, 8 \mathrm{~mm})$

were also higher. Then in our experiment, we selected 100 as the optimal discharge power.

Figure 9 showed the results of the $R$ of $0.1 \%$ and $0.15 \% \mathrm{CV}$ solutions. At the same discharge time, it is clear to see that the $\mathrm{R}$ was higher in $0.1 \%$ concentration than $0.15 \%$ concentration for the less dye macromolecule in the solution. At discharge time of $120 \mathrm{~s}$, both the $\mathrm{R}$ of the solutions $(0.1 \%$ and $0.15 \%)$ was $100 \%$. 


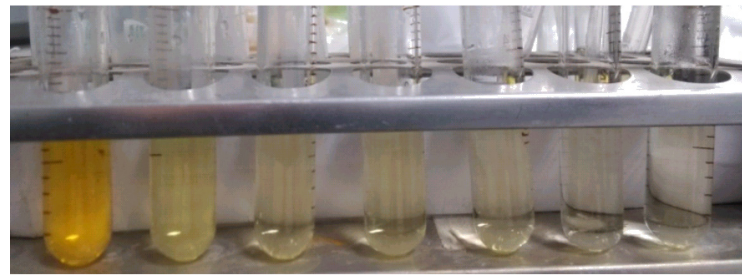

Fig. 11. The pictures of $\mathrm{CV}$ dye at discharge time of $0 \mathrm{~s}, 20 \mathrm{~s}, 40 \mathrm{~s}, 60 \mathrm{~s}, 80 \mathrm{~s}, 100 \mathrm{~s}$ and $120 \mathrm{~s}$

\subsection{The optimal plasma discharge con-} ditions of MO wastewater remediation

$0.1 \% \mathrm{MO}$ solutions were treated at $100 \mathrm{~W}, 8$ $\mathrm{mm}$ and discharge time of $20 \mathrm{~s}, 40 \mathrm{~s}, 60 \mathrm{~s}, 80 \mathrm{~s}$, $100 \mathrm{~s}$ and $120 \mathrm{~s}$, respectively. Figure 10 showed the $\mathrm{R}$ of the $\mathrm{CV}$ solutions. When the time increased, the $\mathrm{R}$ of the CV solution was effectively increased. At discharge time of $90 \mathrm{~s}$, the decoloration rate of the $\mathrm{CV}$ solution was as high as $90 \%$. With the extending of discharge time to 3 $\mathrm{min}$, the $\mathrm{R}$ of the $\mathrm{CV}$ solution was nearly to 100 $\%$. The pictures of MO solution at different discharge time were showed in Fig. 11. It is clear that the color of MO solutions gradually fade. Compared with the results of CV solutions, it is also concluded that $\mathrm{MO}$ dye was difficult to decolorate than $\mathrm{CV}$.

Figure 12 was the results of the $\mathrm{R}$ of $\mathrm{MO}$ solutions at different discharge power. Figure 13 was the $t$ results of the $\mathrm{R}$ of $0.1 \% \mathrm{CV}$ solutions and $0.3 \% \mathrm{CV}$ solutions. The same results can be obtained for the MO solutions. The optimal discharge power was $100 \mathrm{~W}$. At the same time the decoloration rate of solutions with $0.1 \%$ concentration was than $0.3 \%$ concentration.

\subsection{Energy yield for decoloration}

The energy yield is an important parameter for appraising the treatment method. The energy yield of the plasma discharge reactor was calculated by Eq. (5) [13]:

where,

$$
C_{50}=0.5 \times \frac{C_{0}-V_{0}}{P t_{50}}
$$

$G_{50}(\mathrm{~g} / \mathrm{kWh})$ - the energy yield;

$C_{0}(\mathrm{~mol} / \mathrm{L})$ - the molar concentration;

$V_{0}(L)$ - volume of treated solution in liters;

$P(W)$ - power of the reactor;

$t_{50}$ - the time in seconds required for $50 \%$ conversion.

The energy yield obtained in the present work was $0.24 \mathrm{~g} / \mathrm{kWh}$ for $\mathrm{MO}$ dye and $0.36 \mathrm{~g} /$ $\mathrm{kWh}$ for CV dye. For MO dye in the other reports, the energy yield was 0.44 with pulse diaphragm discharges with air bubbling [14], 0.45 with gas-liquid pulsed discharge [13] and $0.09 \mathrm{~g} / \mathrm{kWh}$ with pulsed streamer and spark discharges in water [15].

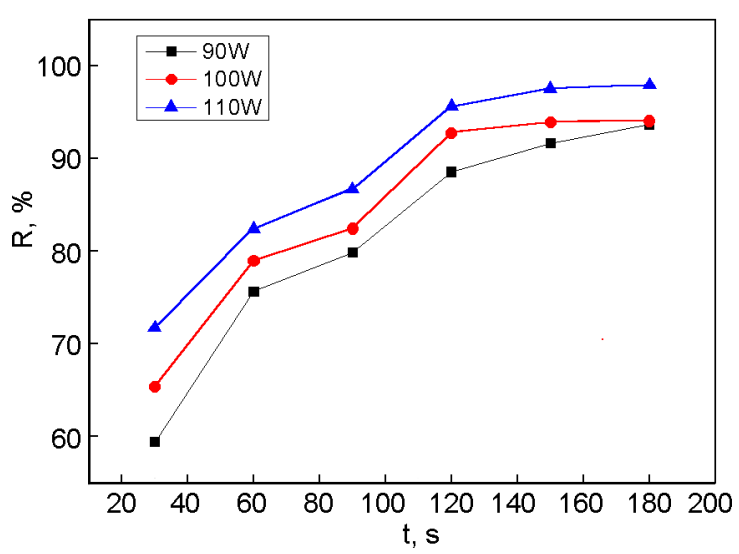

Fig. 12. The $\mathrm{R}$ of $\mathrm{CV}$ solutions at different discharge power

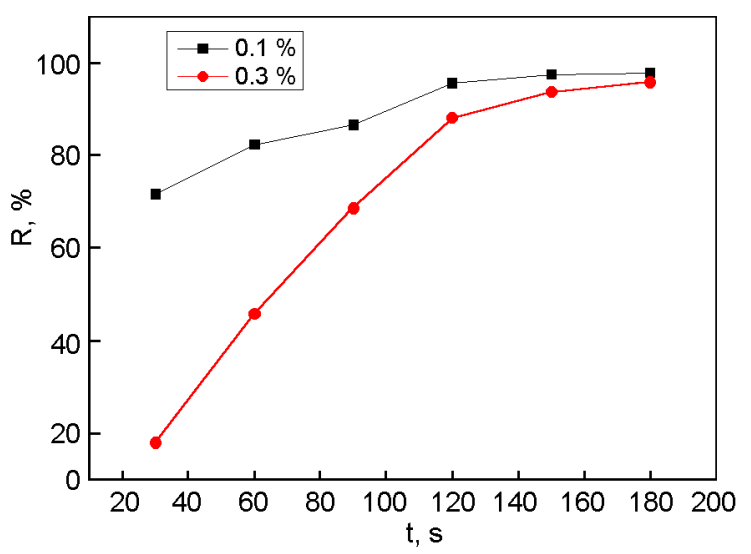

Fig. 13. The R of $0.1 \%$ and $0.3 \% \mathrm{MO}$ solutions $(100 \mathrm{~W}, 8 \mathrm{~mm})$

\section{Conclusions}

In this study, DBD plasma was proposed for the discoloration of $\mathrm{CV}$ and $\mathrm{MO}$ dye, and the following conclusions were reached. (1) CV solution can be effectively used as $\mathrm{OH}$ radical indictor. (2) During plasma discharge, a large number of strong $\mathrm{OH}$ oxidizing species was produced in water and attacked the dye molecules, resulting in the bleaching of the solution. The $\mathrm{OH}$ radical can survive longer in water solution than in gas state. Water solution increased the dye decoloration efficiency. (3) When the discharge time increased, the decoloration rate increased. $0.1349 \%$ CV solution need 2 min to fade and $0.1 \% \mathrm{MO}$ solution need $3 \mathrm{~min}$ to fade at discharge condition of $100 \mathrm{~W}$ and $8 \mathrm{~mm}$. (4) The energy yield obtained in this investigation was $0.24 \mathrm{~g} / \mathrm{kWh}$ for MO dye and $0.36 \mathrm{~g} / \mathrm{kWh}$ for CV dye.

\section{Acknowledgements}

This work was financially supported by $\mathrm{Na}$ tional Engineering Research Center of Seafood (2012FU125X03); Key University Science and Technology Platform of Liaoning Province (No. 
2011-191); Liaoning province colleges' outstanding talent support program (No.LJQ2015008).

\section{References}

1. B. Jiang, J. Zheng, S. Qiu, M. Wu, et.al., Chem. Engin. J., 236, 368, 2014.

2. P. Baroch, N. Satio, O Takai, J. Phys. D: Appl. Phys., 41, . 085207, 2008.

3. R. P. Joshi, S. M. Thagard, Plasma Chem. Plasma Proc., 33, 1, 2013.

4. R. P. Joshi, S. M. Thagard, Plasma Chem. Plasma Proc., 33, 17, 2013.

5. M. Tichonovas, E. Krugly, V. Racys, R. Hippler, et.al., Chem. Engin. J., 229, 9, 2013.

6. G. Chen, M. Zhou, S. Chen, W. Chen, J. Hazardous Mater., 72, 786-, 2009.

7. Y. Wang, X. Y. Shen, J. Macromolec. Scie., Part B: Physics, 51, 662, 2012.
8. A.A. Joshi, B.R. Locke, P. Arce, W.C. Finney, J. Hazardous Mater., 41, 3, 1995.

9. C. B. Lee, Y. H. Na, T. E. Hong, E. H. Choi, et.al., Appl Phys Lett, 105,.073702, 2014.

10. M. Y usupov, E. C. Neyts, P. Simon, et.al., J. Phys. D Appl. Phys., 47, 025205, 2014.

11. C. Liu, J. Zou, J.Tianjin Univ. (in Chinese), 37, 189, 2004.

12. Y. Wang, B. Yuan, Y. C. Ji, H. Li, Carbohyd. Polym, 97, 518, 2013,.

13. B. Sun, N. N. Aye, Z. Gao, D. Lv, et.al., J. Environment. Scie., 24, 840, 2012.

14. L. Zhang, B. Sun, X. M. Zhu, J. Electrostat., 67, $62,2009$.

15. A. T. Sugiarto, S. Ito, T. Ohshima, M. Sato and J. D. Skalny, J. Electrostat., 58, 135, 2003. 